\title{
Stepwise analysis of reactions and reacting flow in a dual fluidized bed gasification reactor
}

\author{
R. K. Thapa \& B. M. Halvorsen \\ Institute for Process, Energy and Environmental Technology, \\ Telemark University College, Norway
}

\begin{abstract}
Dual fluidized bed gasification reactors are used in a wide range of biomass conversion processes. Some of the important processes are steam gasification of biomass for combined heat and power (CHP) production and synthesis processes leading to production of liquid and gaseous biofuels. Gas-solid multiphase flow and thermochemical processes are responsible for overall performance of the reactor. The multiphase flow involves reacting flow of solids (biomass and bed materials) with gases (steam and product gas components). The thermochemical process involves devolatilization of wood followed by steam gasification, $\mathrm{CO}_{2}$ gasification, methanation, water gas shift and methane reforming. In order to optimize the performance of the reactor, it is important to study each of the global reaction and their reacting flow separately.

A computational model has been developed to study the reaction kinetics and the reacting flow in a dual fluidized bed gasification reactor. The model has been validated against the measurements of gas composition in an operating plant for biomass gasification. The reactions are simulated individually using commercial Computational Particle Fluid Dynamic (CPFD) software Barracuda VR 15. The results of simulations such as product gas compositions $\left(\mathrm{CO}, \mathrm{CO}_{2}, \mathrm{CH}_{4}\right.$, and $\left.\mathrm{H}_{2}\right)$, wood particle volume fraction and char particle volume fractions are compared for each individual reaction. The results show each of the global reaction contributes to the product gas composition differently. The volume fractions of wood and char particles show that the residence time of wood and char particle in the reactor is different for different reactions. The contribution of devolatilization, steam gasification and water-gas shift in the product gas heating value is more significant than others.

Keywords: biomass gasification reactor, dual fluidized bed, CPFD, steam gasification, reaction kinetics, reacting flow.
\end{abstract}




\section{Introduction}

Biomass is a renewable source of energy that does not contribute to greenhouse gas emission. Moreover, emission of sulphur and nitrogen compounds from the biomass is less in comparison to coal [1]. These factors make biomass an attractive source of energy. Wood is the largest representative among the biomass [2]. The energy recovery from the biomass is possible through the thermo-chemical conversion processes such as pyrolysis and gasification. Actually, pyrolysis is also a part of the gasification process. The gasification process mainly occurs in two stages: first devolatilization (pyrolysis) of biomass and then char conversion [3]. Char conversion can be achieved through the gasification of the char using gasification agents. The gasification agents can be air, oxygen, carbon-dioxide and steam. There are different types of gasification reactors such as fixed bed, moving bed and fluidized bed. Fluidized bed reactors are most popular among them due to their high heat and mass transfer rates that result in high rate of product gas. Among the different fluidized bed gasification reactors, steam gasification of wood in dual fluidized bed is one of the promising technologies for biomass conversion.

Dual fluidized bed gasification reactors are used in wide range of biomass conversion processes. Some of the important processes are gasification of biomass for combined heat and power (CHP) production and synthesis processes leading to production of liquid and gaseous biofuels [4, 5]. The principle of dual fluidized bed gasification process is shown in Figure 1.

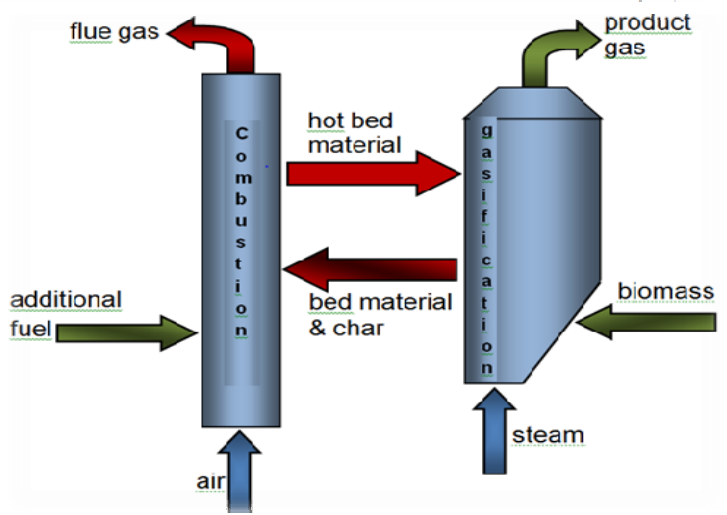

Figure 1: Principle of dual fluidized bed gasification technology.

The reactor is divided into two separate zones: combustion and gasification. The combustion zone is a circulating fluidized bed reactor. The fluidizing gas is air. In the combustion zone, inert bed materials such as olivine particles or quartz sand are heated by burning fuels. The heated bed material is then circulated to the gasification reactor. The purpose of the recirculation of bed material is 
to supply necessary heat for the endothermic gasification reaction in the gasification zone.

The gasification zone is a bubbling fluidized bed reactor for steam gasification of biomass. The fluidizing gas is a high temperature steam. Biomass feed to the gasification reactor is mixed with hot bed materials. The biomass in the reactor is dried and devitalized to produce volatile gases and solid char particles. The char particles further react with steam to produce a mixture of combustible gases in addition to some $\mathrm{CO}_{2}$ and water vapour. The technology is developed by Vienna University of Technology in Austria. The technology is demonstrated as a successful story in the example of the biomass CHP plant in Güssing, Austria [6].

Despite the novelty of the technology, the efficiency of the technology needs to be increased in order to make it sustainable and competitive in the world energy market. It is believed that the thermo-chemical process inside the gasification rector is one of the major factors that can increase the performance of the reactor significantly. The thermo-chemical process inside the reactor depends on a number of operating parameters as well as the design of the reactor. Experimental study of the thermo-chemical behaviour has been difficult due to high operating temperature in addition to time consumption and material costs related to the requirements of constructing hot models and pilot plants. The design of the reactor needs to be changed in order to study feed location of bed material and biomass. Therefore, taking a benefit of rapidly growing computational prediction methods such as CPFD simulation is a fast and economic way to study and optimize the reactors. This work is focused on the analysis of thermochemical process in the gasification reactor and the effect of fluid-dynamic parameters on the process.

\section{Gasification reactions}

In the dual fluidized bed gasification system, the gasification reactor is regarded as the heart of the system. Fluid-dynamic properties and the thermo-chemical process in the gasification reactor are responsible for the overall efficiency of the reactor. The thermo-chemical process in the gasification reactor constitutes several reactions. Identification of all the reactions and their kinetics and simulating them are almost impossible [7]. However the processes can be virtually divided into a group of separate sub-process which constitutes the major global processes.

Devolatilization is the first step of the biomass gasification. First, the biomass is dried and then it undergoes the process of devolatilization. The process is endothermic. All necessary heat for the process is supplied by the hot bed materials which circulate between two zones of the reactor.

The quantity and quality of volatiles produced in this process significantly affect the overall gas composition of the final product gas. The heating value of the product gas depends on its composition.

The biomass investigated in this work is wood chips. The wood is assumed as a virtual chemical compound with the elemental analysis given in Table 1 [8]. 
Table 1: $\quad$ Elemental analysis of wood.

\begin{tabular}{|l|l|}
\hline Elements & Wt.\% \\
\hline Carbon, C & 48.6 \\
\hline Hydrogen, H & 5.6 \\
\hline Oxygen, O & 45.6 \\
\hline Nitrogen, N & 0.2 \\
\hline
\end{tabular}

The elements included in the table are only the major elements with significant weight fraction.

The ash content (composition of elements such as potassium, calcium, sodium, silicon, phosphorous and magnesium) in wood is less than $1 \%$ [9]. The nitrogen content of the wood is $0.2 \%$. For the simplicity of modelling all these minor components are neglected. Finally, the process of devolatilization of the wood can be modelled as shown in Equation (1).

$$
\mathrm{C}_{x} \mathrm{H}_{y} \mathrm{O}_{z}=a \mathrm{CH}_{4}+b \mathrm{CO}+d \mathrm{CO}_{2}+e \mathrm{H}_{2}+f \mathrm{C}_{x} \mathrm{H}_{y}+g \mathrm{C}+h \mathrm{H}_{2} \mathrm{O}
$$

The kinetics of devolatilization is assumed as given by equation (2).

$$
r_{0}=264000 m_{s} \theta_{f} \exp \left(\frac{-12629}{T}\right)
$$

The kinetics of the conversion process depends on the structure of the biomass and the heat and mass transfer inside the biomass particles [10]. Temperature, pressure and heating rate are the main operating parameters.

The second step of the gasification process is the char gasification. The reaction of char particles with fluidizing steam is the major process of char conversion. Hence the name of the process is steam gasification. The char particles also react with the $\mathrm{CO}_{2}$ and $\mathrm{H}_{2}$ gases produced during devolatilization of the wood. The major global reaction and reaction kinetics are given in Table 2 $[11,12]$.

Char yield and char reactivity are important in determining the capacity of the gasification reactor [8]. Minimum residual char production and maximum reactivity of char makes the reactor more efficient.

The chemistry described in the Table 2 is specified as mass action kinetics [13]. The reactions are described by stoichiometric equations and their rates. The effect of particle concentration on the reaction rate will be included within the reaction coefficient $\mathrm{k}$. During the overall process of gasification, the biomass particles are heated from just above the ambient temperature up to the gasification reaction temperature (about $850^{\circ} \mathrm{C}$ ) [14].

Besides the heterogeneous char gasification, the third step of the process is homogeneous gas-gas reaction. This step involves water-gas shift reaction and 
methanation. Starting with the devolatilization of wood, all the reactions are simulated individually in order to study their contribution to the whole biomass steam gasification process.

Table 2: Reaction kinetics used in the simulations.

\begin{tabular}{|c|c|}
\hline Reactions & Reaction kinetics \\
\hline $\begin{array}{c}\text { Steam gasification } \\
\mathrm{C}+\mathrm{H}_{2} \mathrm{O}=\mathrm{H}_{2}+\mathrm{CO}\end{array}$ & $r_{1}=2.7 \times 10^{7} m_{s} P^{0.73} \theta_{f} \exp \left(\frac{-26506}{T}\right)\left[\mathrm{H}_{2} \mathrm{O}\right]$ \\
\hline $\begin{array}{c}\text { Carbon-dioxide } \\
\text { gasification } \\
\mathrm{C}+\mathrm{CO}_{2}=2 \mathrm{CO}\end{array}$ & $r_{2}=1.12 \times 10^{8} m_{s} P^{0.31} \theta_{f} \exp \left(\frac{-29518}{T}\right)\left[\mathrm{CO}_{2}\right]$ \\
\hline $\begin{array}{c}\text { Methanation } \\
\mathrm{O} .5 \mathrm{C}+\mathrm{H}_{2}=0.5 \mathrm{CH}_{4}\end{array}$ & $r_{3}=1.368 \times 10^{-3} m_{s} \mathrm{~T} \exp \left(\frac{-8078}{T}-7.087\right)\left[\mathrm{H}_{2}\right]$ \\
\hline $\begin{array}{c}\text { Water- gas shift reaction } \\
\mathrm{CO}+\mathrm{H}_{2} \mathrm{O}=\mathrm{CO}_{2}+\mathrm{H}_{2}\end{array}$ & $r_{4}=7.68 \times 10^{10} m_{s} \mathrm{~T} \exp \left(\frac{-36640}{T}\right)[\mathrm{CO}]^{0.5}\left[\mathrm{H}_{2} \mathrm{O}\right]$ \\
\hline $\begin{array}{c}\text { Methane reforming } \\
\mathrm{CH}_{4}+\mathrm{H}_{2} \mathrm{O}=\mathrm{CO}_{+} \mathrm{H}_{2}\end{array}$ & $r_{5}=3.0 \times 10^{5} \mathrm{~T} \exp \left(\frac{-15042}{\mathrm{~T}}\right)\left[\mathrm{CH}_{4}\right]\left[\mathrm{H}_{2} \mathrm{O}\right]$ \\
\hline
\end{tabular}

\section{Model description}

There is an increasing application of Computational Fluid Dynamics (CFD) modelling approach in the prediction of gas-solid multiphase flow. EulerianEulerian and Eulerian-Langrangian are the two approaches commonly used in the CFD modelling. The difference between the two approaches lies in the modelling of gas-solid interaction.

In the Eulerian-Eulerian approach, the solid particles are considered as continuous phase interpenetrating and interacting with the gas phase. Both the fluid and solid are averaged by a statistical procedure. The averaging procedure creates many unclosed terms [7]. In order to close the terms, constitutive equations are required for particle phase as well as the particle gas interactions. These constitutive equations are derived from the kinetic theory of granular flow [15]. There are mainly two short-comings related to this approach. The closure models describing the mass, momentum and energy transfer between multiple continuous phases are complicated and not universally valid [16]. Separate closure models are valid only for mono-dispersed particles which makes it almost impossible to solve the multiphase flow with a wide range of particle sizes [7].

Eulerian-Langrangian approach tracks individual particles in time and space. The equations of mass, energy and motion are solved for individual particles. The approach offers the most accurate description of the particle motion 
(translational, rotational and particle-particle collision), chemical reaction and heat-mass transfer between the dispersed phase and the gas phase at the individual particle scale.

There are quite a lot of publications describing inert particle simulations using DEM model but only few describing particle systems involving heat and mass transfer and chemical reactions. In thermal reacting flows, the size of the particles changes due to devolatilization and gasification. Moreover rates of reactions and fluid temperatures depend on the solid surface areas, types of solid materials and discrete solid temperatures [7].

The CPFD numerical methodology incorporates the multi-phase particle in cell (MP-PIC) method for calculating dense particle flows. The CPFD method is a hybrid numerical method, where the fluid phase is solved using Eulerian computational grid and the solids are modeled using Langrangian computational particles. In MP-PIC, an isotropic particle stress gradient is added to the equation of motion of the particles. This addition enables the method to calculated flows of particles with any volume fraction from the dilute to the closed packed limits $[17,18]$.

In order to apply CPFD methodology for heat transfer and chemistry with solid material pyrolysis, an enthalpy equation is solved to calculate flows with large chemistry-induced temperature variations. The bed in the gasifier has a complex gas and solid flow patterns that help determine the gas-solid and gasgas chemical conversion rates [7].

The CPFD methodology solves the fluid and particle equations in three dimensions. The fluid dynamics is described by averaged Navier-Stokes equations with strong coupling to the particle phase.

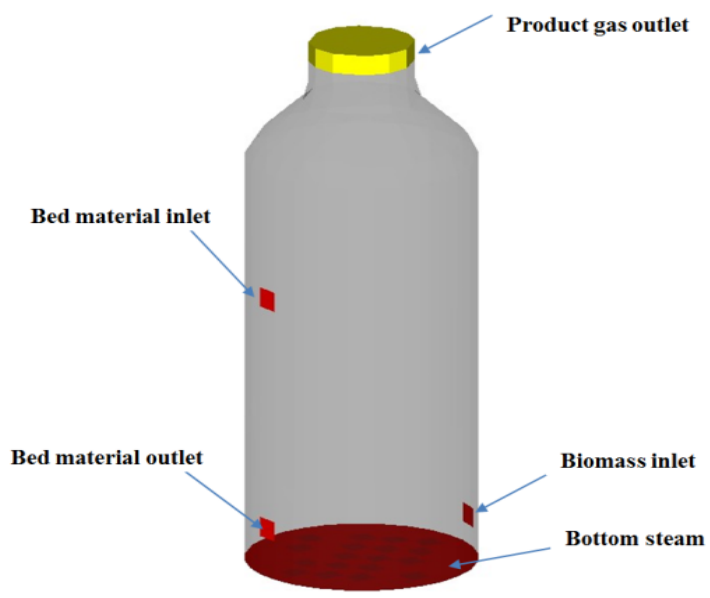

Figure 2: Model of gasification reactor. 
The CPFD numerical methodology has been applied in this work. The aim of this work is to study the thermo-chemical process in the gasification zone. The reactor is modelled as bubbling fluidized bed reactor. The combustion zone is replaced by input and output of bed material to the gasification reactor as shown is Figure 2. The simulation parameters and boundary conditions applied in the simulations are presented in Table 3.

Table 3: Parameters used in the simulations.

\begin{tabular}{|l|c|c|l|c|c|}
\hline Parameter & Unit & Value & Parameter & Unit & Value \\
\hline $\begin{array}{l}\text { Bottom steam feed } \\
\text { rate }\end{array}$ & $\mathrm{kg} / \mathrm{h}$ & 112 & Biomass feed rate & $\mathrm{kg} / \mathrm{h}$ & 112 \\
\hline $\begin{array}{l}\text { Steam feed } \\
\text { temperature }\end{array}$ & $\mathrm{K}$ & 1073 & $\begin{array}{l}\text { Biomass inlet } \\
\text { temperature }\end{array}$ & $\mathrm{K}$ & 400 \\
\hline $\begin{array}{l}\text { Fluidization } \\
\text { velocity }\end{array}$ & $\mathrm{m} / \mathrm{s}$ & 0.64 & $\begin{array}{l}\text { Bed material } \\
\text { circulation rate }\end{array}$ & $\mathrm{kg} / \mathrm{h}$ & 5980 \\
\hline $\begin{array}{l}\text { Reaction } \\
\text { temperature }\end{array}$ & $\mathrm{K}$ & $\begin{array}{c}1100 \\
-\end{array}$ & $\begin{array}{l}\text { Bed material inlet } \\
\text { temperature }\end{array}$ & $\mathrm{K}$ & 1150 \\
\hline Reactor diameter & $\mathrm{m}$ & 0.55 & Reactor height & $\mathrm{m}$ & 2 \\
\hline Initial bed height & $\mathrm{m}$ & 0.60 & $\begin{array}{l}\text { Wood feed position } \\
\text { from the bottom of } \\
\text { the reactor }\end{array}$ & $\mathrm{m}$ & 0.15 \\
\hline
\end{tabular}

\section{Results and discussion}

A series of simulations have been performed for the individual reactions occurring in the gasification reactor. The reaction sequences involved in the separate simulations are presented in Table 3.

Table 4: Reaction sequences involved in the simulations.

\begin{tabular}{|l|l|}
\hline $\mathrm{SN}$ & Reactions \\
\hline 1 & Volatilization \\
\hline 2 & Volatilization + steam gasification \\
\hline 3 & Volatilization $+\mathrm{CO}_{2}$ gasification \\
\hline 4 & Volatilization + methanation \\
\hline 5 & Volatilization + water gas shift reaction \\
\hline 6 & Volatilization + methane reforming \\
\hline 7 & Total reactions \\
\hline
\end{tabular}


The sequences are further used as reaction sequence number 1, 2, 3, 4, 5, 6 and 7 for the description of the simulations.

The initial step of the simulation is volatilization of biomass which is the preliminary step for the rest of global reactions. Each of the reactions is simulated for the identical operating conditions and parameters. The simulations were run for $300 \mathrm{~s}$ of real time. The volume percent of accumulated product gases are monitored during the simulation. The results of the simulation for reaction sequence 7 are used to calculate the product gas volume percent in dry basis. The volume percentages of the gases are compared with real data from the biomass gasification plant in Güssing, Austria. The results show a reasonable agreement between simulation and plant data.

During the simulation time, the accumulated quantities of gas species leaving the reactor are monitored. The accumulated gas compositions for each of the reactions are compared in Fig. 4. The reaction sequence is the same as given in Table 3 . The simulation sequence 1 represents the volatilization of wood chips.

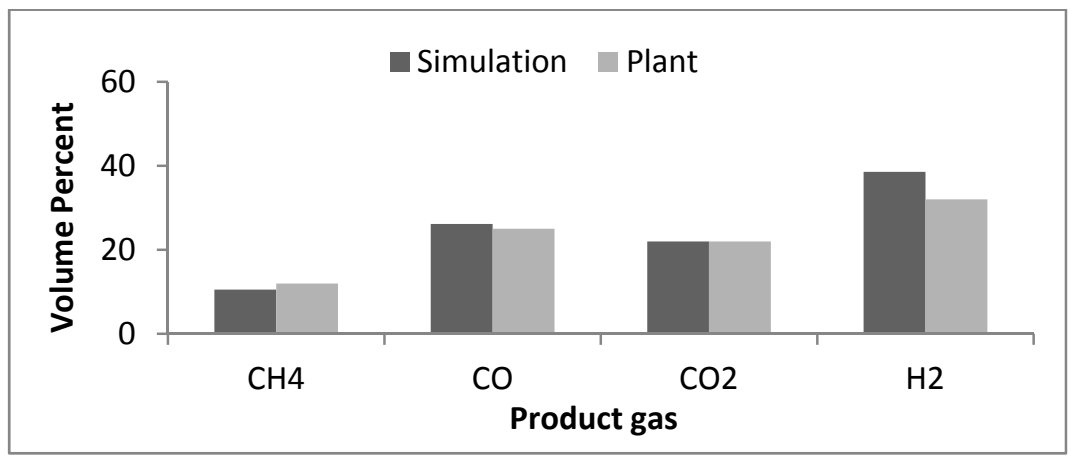

Figure 3: Comparison of gas volume fraction of simulation with plant data.

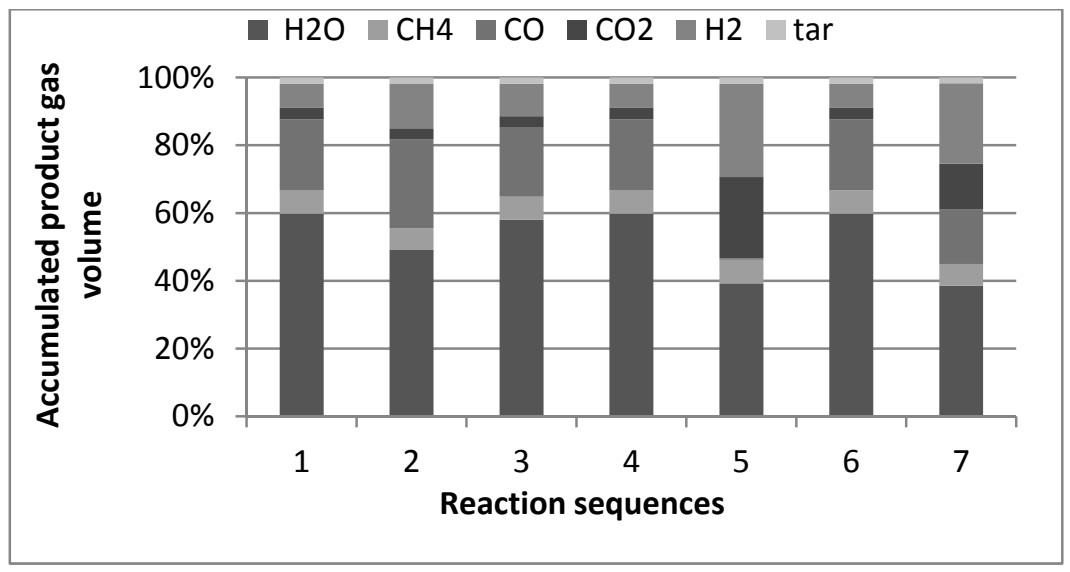

Figure 4: Accumulated volume percent of gas composition. 
The steam to fuel ratio for the simulation is 1 and this ratio is one of the important parameters of the steam gasification process. Insufficient amount of steam in the reactor will have a negative effect on the product gas composition. Excess steam into the reactor makes excess amount of steam in the product gas. On the other hand, steam acts as fluidizing gas and the flow behavior and fluidization properties depend on the steam flow rate. Figure 4 shows that the maximum percent of steam occurs in the product gas in the stage of volatilization. The significant decrease in the steam indicates the steam consumption in the simulation sequences 2, 5 which are the steam gasification and water-gas shift reaction. Only small amount of steam is used for $\mathrm{CO}_{2}$ gasification. The major part of methane is formed during the volatilization of the biomass.

Most of the $\mathrm{CO}$ gas is produced during volatilization and steam gasification reaction and a significant part is consumed during water gas shift reaction contributing to increase the content of $\mathrm{H}_{2}$ and $\mathrm{CO}_{2}$. The volatilization, steam gasification and water-gas shift reactions are responsible for further hydrogen formation. A significant percentage of the hydrogen is formed during the watergas shift reaction. The amount of hydrocarbons as tar does not change since their reactions are not considered in the model.

The contours of particle volume fraction of wood and char are presented in Figure 5 and Figure 6 respectively. The contours are snap shots at the simulation time of 300 s.

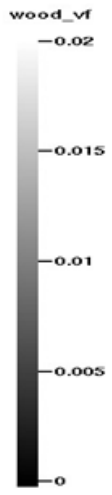

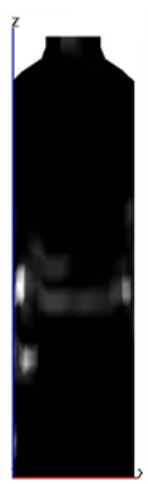

1

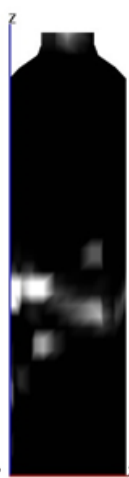

2

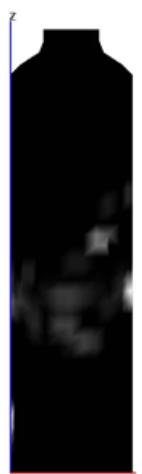

3

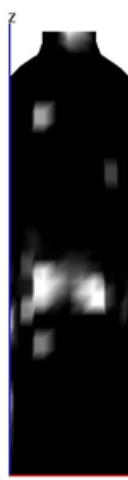

4

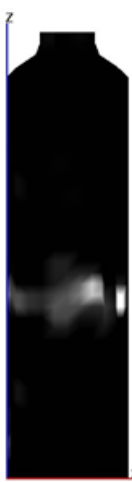

5

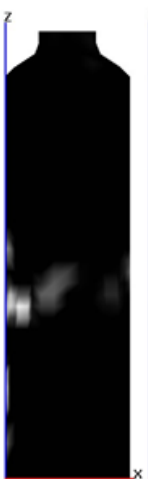

6

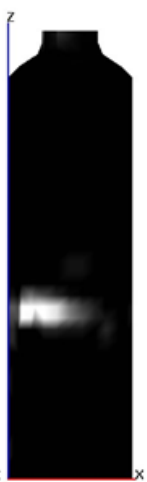

7

Figure 5: Contours of wood particle volume fraction at simulation time 300s.

Important information of the behavior of the reacting solid particles can be found from the contours of their volume fraction. The first obvious information is the major part of unreacted wood particles is floating on the top of the dense bed. The bed material and wood particles does not seem to be well mixed as required by the properties of fluidized bed system. The steam, biomass and bed material feeding velocities, biomass and bed material feeding positions, gas particle densities and reactor geometry are some of the parameters that can be 
optimized to get the desired mixing. The contours of char volume fraction shown in Figure 6 are different for the different reactions. The similarity between them is that the char particles are mainly located on the top of the bed.

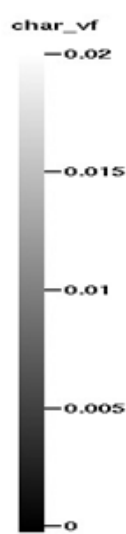

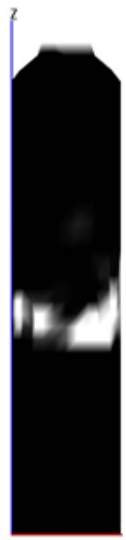

1

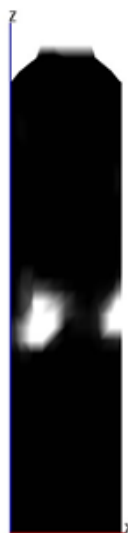

2

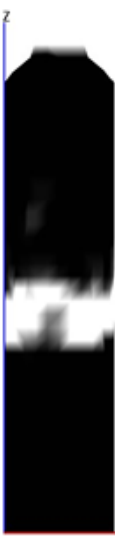

3

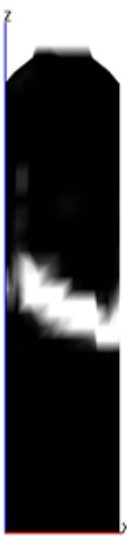

4

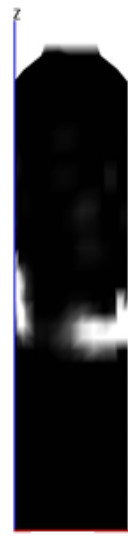

5

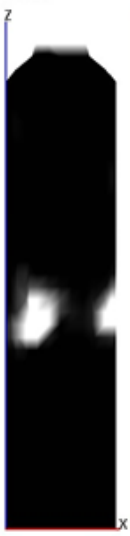

6

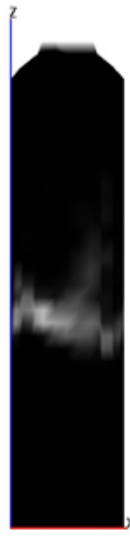

7

Figure 6: Contours of char particle volume fractions at simulation time of 300s.

Reaction sequence 1 is only volatilization and no char conversion is taken place. Consequently the volume fraction of char is high in this case. The high char particle volume fraction on reactions sequence 5 and 6 indicate low char conversion. The char particle volume fraction on steam gasification (sequence 2) is less than that of $\mathrm{CO}_{2}$ gasification and methanation (sequence 3 and 4) indicating that the steam gasification reaction is responsible for more char conversion. The total reaction (sequence 7) shows that the maximum conversion of char is obtained when all the reactions are included.

The contours of char particles in all reactions show the accumulation of the particles on the top of the bed indicating the insufficient mixing between char and bed materials. The exact experimental evidence of bed material and wood/char mixing phenomenon in reacting flow is not found easily in the published literatures. Consequently, the result of the work also indicates the need of further investigation of mixing and segregation of particles in fluidized bed reactors.

\section{Conclusion}

A series of simulations have been performed to investigate the individual reactions involved in biomass steam gasification in a dual circulating fluidized bed gasification reactor. The reactions such as steam gasification, $\mathrm{CO}_{2}$ gasification, methanation, water-gas shift reaction and methane reforming reactions are simulated along with the volatilization of biomass. The simulation parameters such as biomass and bed material circulation rates, bottom steam feed rate, fluidization velocity and reaction temperature are kept constant for all 
reactions. The contribution of the different reactions on the production of combustible gases $\left(\mathrm{H}_{2}, \mathrm{CO}\right.$ and $\left.\mathrm{CH}_{4}\right)$ has been studied. The reactions do not affect significantly the production of $\mathrm{CH}_{4}$. The gas $\mathrm{CH}_{4}$ is mainly produced during devolatilization of the biomass. Steam gasification contributes to significant formation of $\mathrm{CO}$ and $\mathrm{H}_{2}$ components of the product gas. The watergas shift reaction contributes to significant consumption of $\mathrm{CO}$ forming more $\mathrm{H}_{2}$. Steam gasification and water-gas shift reactions are the major contributors to the formation of more hydrogen component in product gas.

\section{References}

[1] Diego, L.F., et al., Modeling of the Devolatilization of Nonspherical Wet Pine Wood Particles in Fluidized beds. Industrial \& Engineering Chemistry Research, 2002. 41: pp. 3642-3650.

[2] Di Blasi, C., Modeling chemical and physical processes of wood and biomass pyrolysis. Progress in Energy and Combustion Science, 2008. 34(1): pp. 47-90.

[3] Di Blasi, C., et al., Product Distribution from Pyrolysis of Wood and Agricultural Residues. Industrial \& Engineering Chemistry Research, 1999. 38(6): pp. 2216-2224.

[4] Bolhar-Nordenkampf, M. and H. Hofbauer. Gasification Demonstration Plants in Austria. in IV. International Slovak Biomass Forum. 2004. Bratislava.

[5] Demitbas, A., Biomass resource facilities and biomass conversion processing for fuels and chemicals. Energy Conversion and Management, 2001. 42: pp. 1357-1378.

[6] Hofbauer, H., R. Rauch, and K. Bosch. Biomass CHP Plant Gussing - A Success Story. in Expert Meeting on Pyrolysis and Gasification of Biomass and Waste. 2002. Strasbourg, France.

[7] Snider, D.M., S.M. Clark, and PP.J. O'Rourke, Eulerian-Lagrangian method for three-dimensional thermal reacting flow with application to coal gasifiers. Chemical Engineering Science, 2011. 66(6): pp. 1285-1295.

[8] Zanzi, R., K. Sjostrom, and E. Bjornbom, Rapid pyrolysis of agriculatural residues at high temperature. Biomass and Bioenergy, 2002. 23: pp. 357366.

[9] Di Blasi, C., et al., Product Distrubution from Pyrolysis of Wood and Agricultural Residues. Industrial \& Engineering Chemistry Research, 1999. 38: pp. 2216-2224.

[10] Gaston, K.R., et al., Biomass Pyrolysis and Gasification of Varying Particle Sizes in a Fluidized-Bed Reactor. Energy \& Fuels, 2011. 25: pp. 3747-3757.

[11] Umeki, K., et al., High temperature steam-only gasification of woody biomass. Applied Energy, 2010. 87(3): pp. 791-798.

[12] Xie, J., et al., Eulerian-Lagrangian method for three-dimensional simulation of fluidized bed coal gasification. Advanced Powder Technology, 2013. 24(1): pp. 382-392. 
[13] Kee, S.B., M.E. Coltrin, and P. Glarborg, Chemically Reacting Flow, ed. John Wiley and Sons. 2003, Hoboken, NJ.

[14] Jand, N. and P.U. Foscolo, Decomposition of Wood Particles in Fluidized beds. Industrial \& Engineering Chemistry Research, 2005. 44: pp. 50795089.

[15] Gidaspow, D., Multiphase Flow and Fluidization Continuum and Kinetic Theory Description. 1994, Boston: Academic Press.

[16] Gerber, S., M. Oeermann, and F. Behrendt. An Euler-Langrange modeling approach for the simulation of wood gasification in fluidized beds. in 9th International Conference on Circulating Fluidized beds. 2008. Hamburg.

[17] Andrews, M.J. and P.J. O'Rourke, The multiphase particle-in-cell (MPPIC) method for dense particle flow. International Journal of Multiphase Flow, 1996. 22: pp. 379-402.

[18] Snider, D.M., An Incompressible Three-Dimensional Multiphase Particlein-Cell Model for Dense Particle Flows. Journal of Computational Physics, 2001. 170(2): pp. 523-549. 